\title{
Ground ice in permafrost on Seymour (Marambio) and Vega Islands, Antarctic Peninsula
}

\author{
Evgeniy ERMOLIN, ${ }^{1}$ Hernán DE ANGELIS, ${ }^{1}$ Pedro SKVARCA, ${ }^{1}$ Frank RAU ${ }^{2}$ \\ ${ }^{1}$ Instituto Antártico Argentino, Cerrito 1248, C1010AAZ Buenos Aires, Argentina \\ E-mail: ivgen52@yahoo.com \\ ${ }^{2}$ Institut für Physische Geographie, Universität Freiburg, Werderring 4, D-79085 Freiburg, Germany
}

\begin{abstract}
Seymour (Marambio) and Vega Islands occur within the continuous permafrost zone of the northeastern Antarctic Peninsula. Results are presented of investigations on the occurrence, distribution, morphology and genesis of ground ice, a key aspect of permafrost research in this region. According to its morphology, ice content, buried ice type and possible upper Quaternary conditions, permafrost is divided into two cryoformations: epigenetic and syngenetic. Based on field and remotesensing data, $76.6 \mathrm{~km}^{2}$ of Seymour Island and $81.0 \mathrm{~km}^{2}$ of Vega Island are characterized by permafrost, with estimated ice contents of 0.06 and $1.41 \mathrm{~km}^{3}$, respectively. Different genetic ground-ice types are distinguished and a regional morphogenetic classification of ground ice is proposed.
\end{abstract}

\section{INTRODUCTION}

Permafrost is an important part of the polar cryosphere due to its sensitivity to environmental conditions. Its occurrence in the Antarctic Peninsula (AP) is well known, though the physical setting, past evolution, origin and initial conditions of ground ice remain poorly understood (Corte, 1983; Fukuda and others, 1992). Permafrost in the northeast AP occurs along the ice-free coastal zones, occupying $<2 \%$ of its total area and $20-30 \%$ of the James Ross Island Group (Suetova, 1968; Rabassa and others, 1982). The northeastern AP is characterized by a dry, subpolar climate with a mean annual air temperature at sea level of around $-5.5^{\circ} \mathrm{C}$ (data from the time series of annual mean temperature at the stations Marambio $\left(64^{\circ} 14^{\prime} \mathrm{S}, 56^{\circ} 37^{\prime} \mathrm{W}\right)$ and Esperanza $\left.\left(63^{\circ} 24^{\prime} \mathrm{S}, 57^{\circ} 00^{\prime} \mathrm{W}\right)\right)$. The region has been subject to increasing warming trends during the last three decades (Skvarca and others, 1998). Available precipitation records are not very reliable, but a reasonable estimate for annual precipitation is around $200-250 \mathrm{~mm}$. Low precipitation and the persistence of strong winds lead to the occurrence of extensive snow-free areas during much of the year, particularly during the winter months. Present permafrost development is therefore controlled by low temperatures and shallow winter snow cover. However, the type of permafrost, its occurrence and the origin of ground ice is also dependent upon the processes of denudation and accumulation that occurred during the Quaternary.

A core aspect of permafrost research is the study of ground ice, i.e. the perennial ice incorporated in permafrost and forming part of it. The comprehensive study of ground ice is important in order to analyze possible paleocryogenic scenarios and to improve present interpretations of past environmental conditions on the AP (Corte, 1983; Kato and others, 1990).

\section{PERMAFROST CONDITIONS IN THE STUDY AREA}

Seymour Island (SI) has a total area of $76.8 \mathrm{~km}^{2}$ and is not currently glacierized. The northern part is composed of Tertiary marine deposits and shows a plateau-type relief reaching an altitude of $200 \mathrm{ma}$ a.s.l. The southern part consists of Cretaceous sandstones showing topography of low ridges and valleys with dominant Quaternary accumulation. Relief development on SI is strongly controlled by exogenic processes in the permafrost zone, especially by eolian deflation (Ermolin and De Angelis, 2002). Vega Island (VI) has an area of $268.5 \mathrm{~km}^{2}$, of which $70 \%$ is covered by glaciers. The ice-free landscape is dominated by mass wasting, fluvioglacial and thermokarst processes (De Angelis and others, 2002). Conspicuous permafrost features occur in ice-free areas of the low coastal plains and upon prominent basaltic plateaus located 200-400 ma.s.l.

The regional distribution of permafrost thickness is not well known, though preliminary information suggests that it is highly variable. Geoelectrical resistivity surveys (Fournier and others, 1990; Fukuda and others, 1992) and theoretical calculations (Ermolin and others, 2002a) suggest a permafrost thickness of $150-200 \mathrm{~m}$ for SI. Available ${ }^{14} \mathrm{C}$ data on Vega and James Ross Islands indicate that at least part of the permafrost in the northeastern AP is of Holocene age (Zale and Karlén, 1989; Ingólfsson and others, 1998). Interpretation of geomorphologic and geocryological surveys indicates the presence of both epigenetic and syngenetic permafrost (Ermolin and others, 2002b).

\section{METHODS}

Fieldwork consisted of mapping the occurrence and distribution of different permafrost types exposed on SI and VI, geocryogenic surveying of outcrops and drilling shallow cores in the upper horizons of permafrost. Mapping was performed by means of remote-sensing data and by using geocryoindicators of ground ice, following criteria described in Kudryavtsev (1979). The use of remote sensing improved the areal coverage of our analysis and the regional mapping of permafrost (Fig. 1). We selected a section of Landsat Enhanced Thematic Mapper Plus (ETM+) image (path/row 216/105), acquired on 21 February 2000, projected on the World Geodetic System 1984 (WGS84) ellipsoid using the Universal Transverse Mercator (UTM) projection, zone $21 \mathrm{E}$. Accurate georeference of field measurements was obtained from differential global positioning system (DGPS) measurements.

Geocryological surveys were based on cryotexture and 


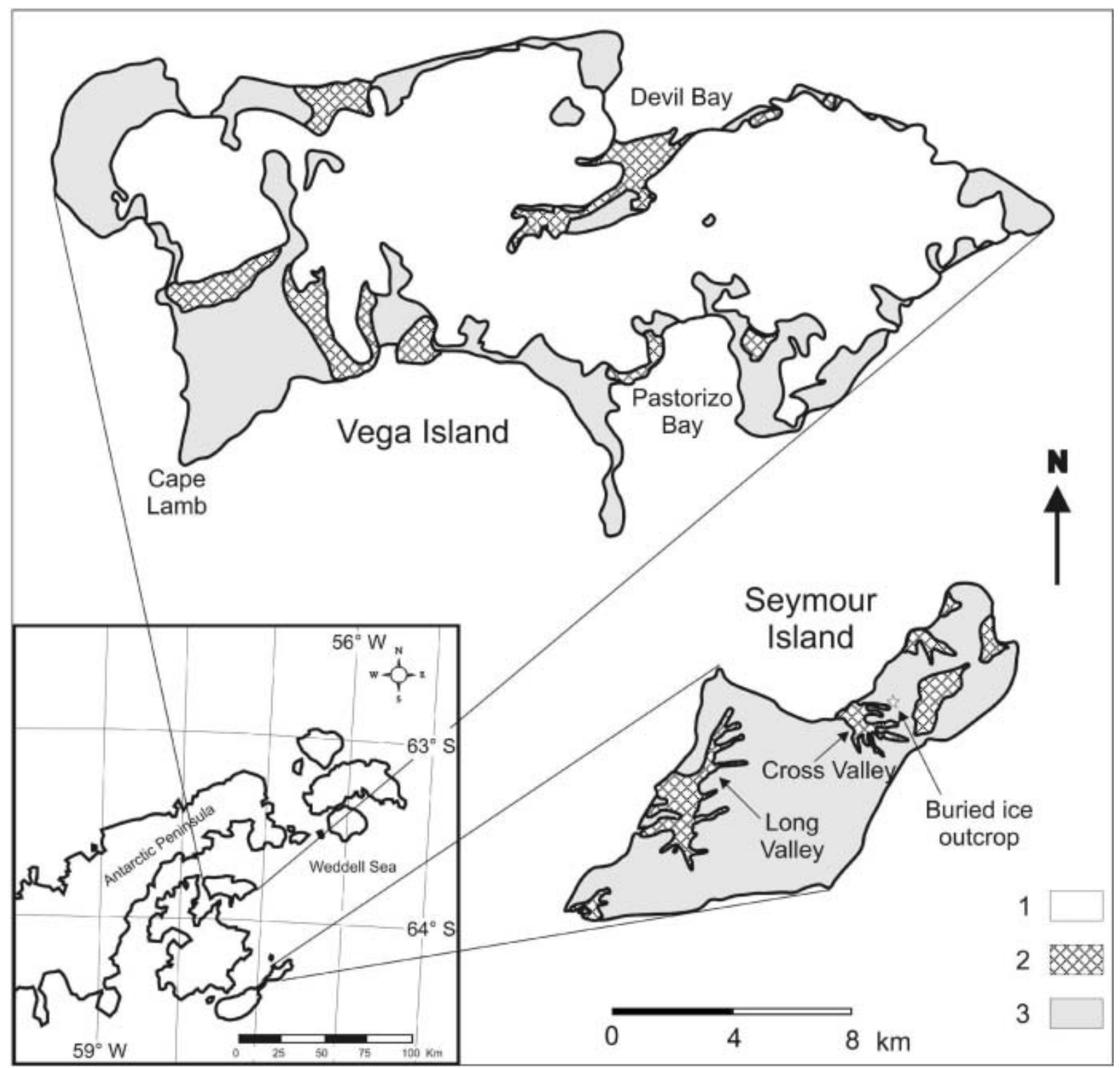

Fig. 1. Location of study area and map of permafrost on Seymour and Vega Islands. 1. Glacier ice. 2. Syngenetic permafrost. 3. Epigenetic permafrost.

cryostructure analysis of different facies of ice-bonded permafrost (Washburn, 1979). Analyses of sediment composition, volumetric ice and total water content were performed on vertical outcrop sections and pits. In addition, the crystallography, grain-size distribution, and occurrence of gas and mineral inclusions of the ground ice were analyzed. These studies allowed us to define different cryoformations based upon common characteristics.

\section{FORMATION AND EXTENT OF GROUND ICE}

Following the original classification of Shumskii (1964), we refer to epigenetic cryoformations when dealing with permafrost units developed on rock or sediment that formed independently of frozen ground conditions, and to syngenetic cryoformations when pointing to permafrost units developed through sedimentary or rock-forming processes that took place under permafrost conditions. Both types of cryoformations can be distinguished based on their specific cryolithology and cryostructures. According to these definitions and taking into account the Quaternary environmental change in the region, the two permafrost types were found. Observations of the numerous permafrost exposures indicate that ground ice only occurs within the upper part of the permafrost zone, with epigenetic cryoformations occurring down to a depth range of $6-8 \mathrm{~m}$, and syngenetic cryoformations down to $12-20 \mathrm{~m}$ depth. Figures 2 and 3 show typical profiles of volumetric ice content in the uppermost $20 \mathrm{~m}$ of epigenetic and syngenetic permafrost on SI and VI, respectively. Areas of ice-rich syngenetic permafrost on SI are limited. They are found in the narrow and deep Cross and Long Valleys (Fig. 1), where the occurrence of friable Quaternary sediments allowed burial and preservation of glacier ice and snowpatches.

Ice-rich permafrost is more extensive on $\mathrm{VI}$, which is partly explained by more recent deglaciation and the profusion of ice-cored moraines on a plain near Pastorizo, Devil Bay and Cape Lamb glaciers. Differentiation on the 


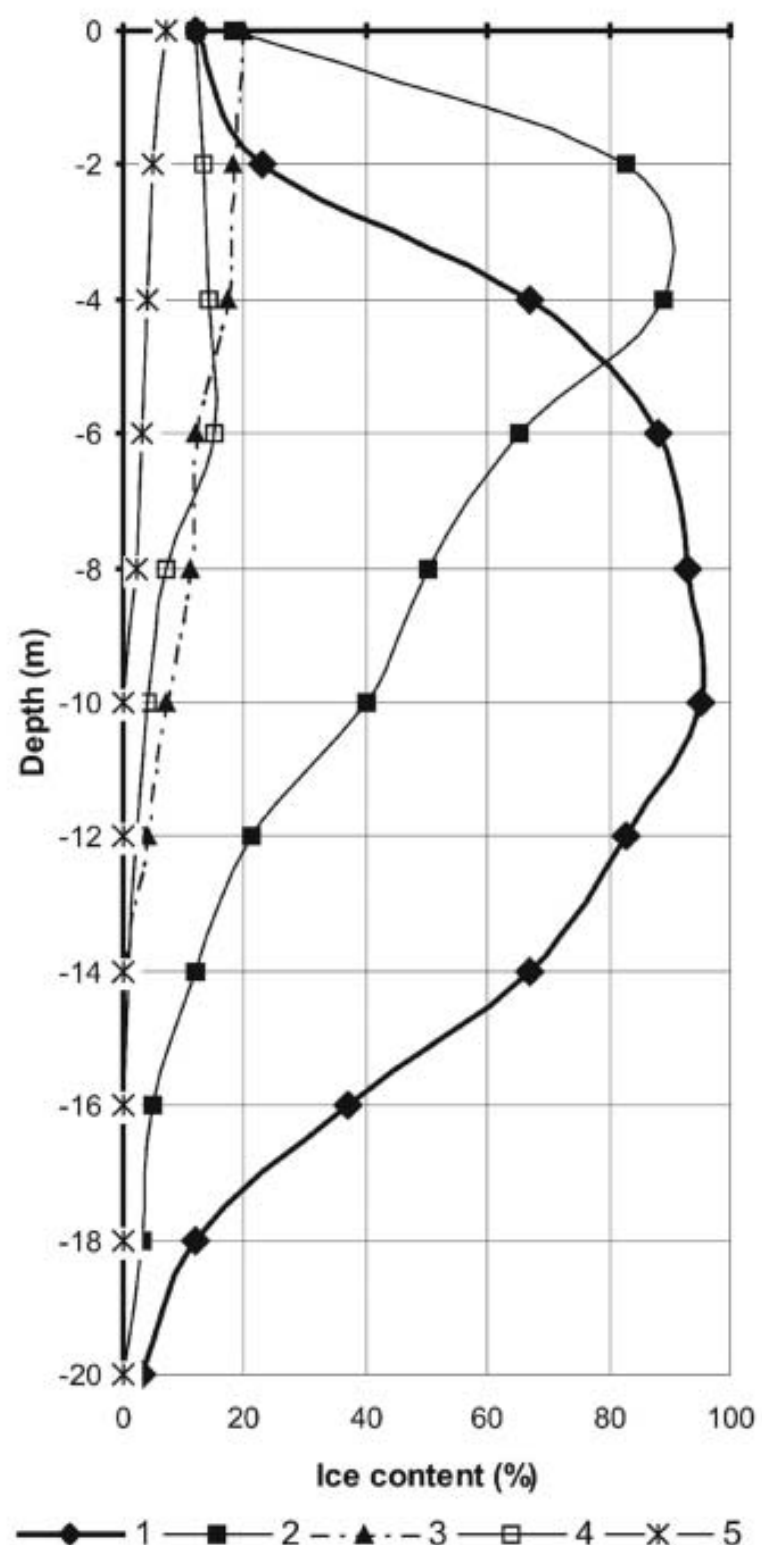

Fig. 2. Volumetric ice content in permafrost on SI. Facies of syngenetic formation: 1 . upper Pleistocene bottom moraine with buried glacial ice; 2. eolian deposits with buried snowpatch; 3 . present alluvial deposits; 4 . Holocene bottom moraine. Facies of epigenetic formation: 5 . Tertiary sediments.

occurrence and distribution of ground ice on both islands defines the conditions of Quaternary deposits and solid rock as well as the preservation of several ground-ice types.

\section{Epigenetic ground ice}

The formation of epigenetic ice is determined by the physical-mechanical properties of the rock and the prevailing temperature and humidity conditions on the surface. Ground ice of this cryoformation is formed mainly by freezing of underground or surface percolation water.

Two distinct facies of epigenetic cryoformation were found: the cryoeluvium developed over massive volcanic rocks on VI and over solid Tertiary sediments on SI. Ground ice in cryoeluvium on basalt plateaus of VI includes fissure, cement and sublimation ice formed in an active weathering

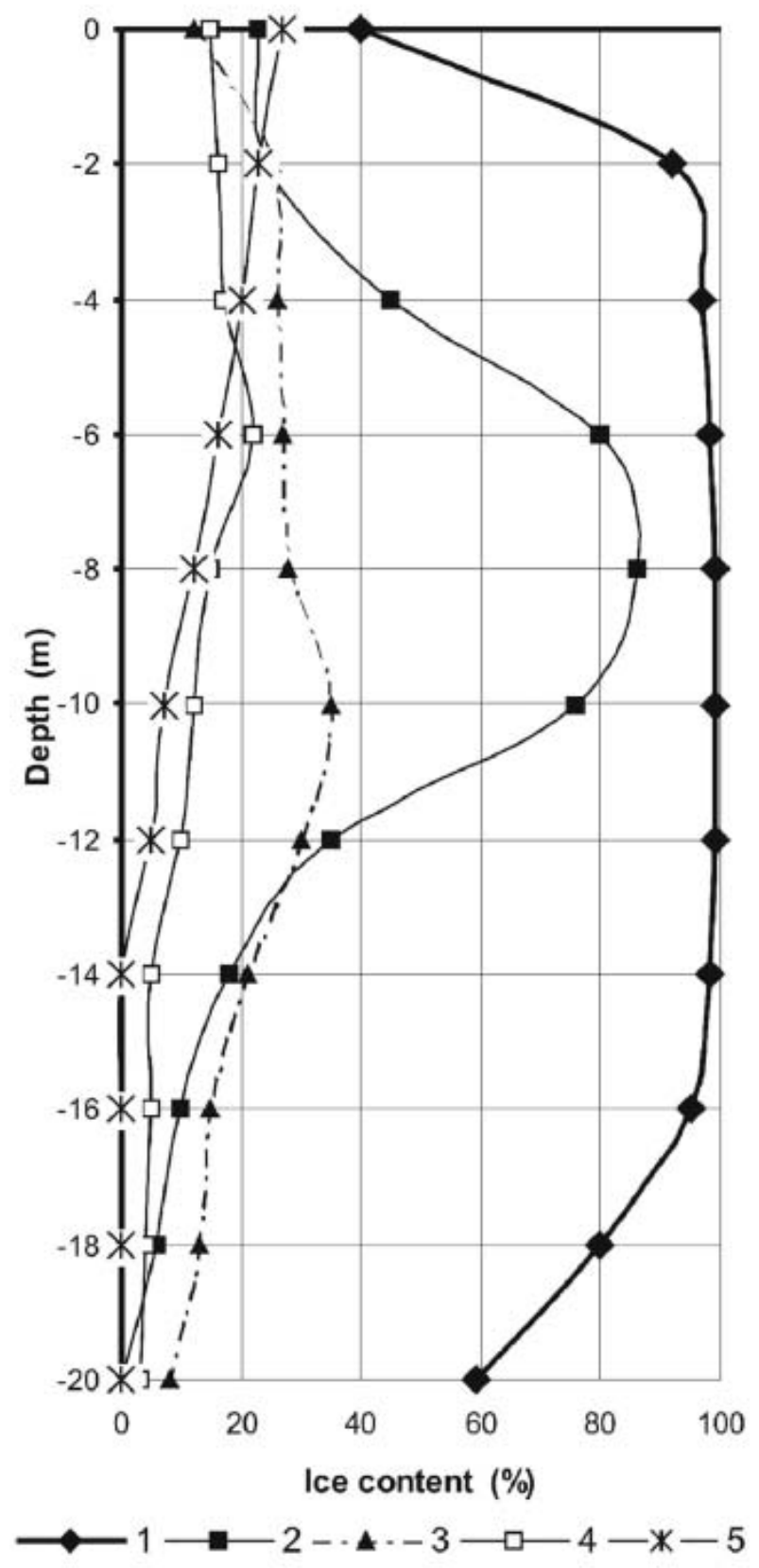

Fig. 3. Volumetric ice content in permafrost on VI. Facies of syngenetic formation: 1. present frontal and lateral moraine with buried glacial ice; 2 . lower Holocene bottom moraine with buried glacial ice; 3. upper Holocene bottom moraine with constitutional ice; 4. fluvioglacial deposits. Facies of epigenetic formation: 5. cryoeluvium.

crust. A maximum volumetric ice content of $10-14 \%$ is observed near the top of the permafrost, though almost no ice of this facies is present below $12-14 \mathrm{~m}$ depth. The ground ice in diagenetic sediments on SI contains insignificant inclusions of cement and segregated ice types, observable down to $6-8 \mathrm{~m}$ depth. Volumetric ice content at this interval does not exceed $8-10 \%$. On the horizontal surfaces of plateaus and eroded plains near the north and west coast, the formation of composite and reformed ice wedges with prime ice veins is observed within the limits of the active layer and the uppermost part of the permafrost. 
Table 1. Volumetric ice content in permafrost of $\mathrm{VI}$ and SI. The ice area of $\mathrm{SI}$ is the area of multi-year snowbank. $\mathrm{Vi}$ is volume of evident ground ice, EF is epigenetic permafrost formation and SF is syngenetic permafrost formation

\begin{tabular}{lcc}
\hline Data & VI & SI \\
\hline Total area $\left(\mathrm{km}^{2}\right)$ & 268.5 & 76.8 \\
Ice area $\left(\mathrm{km}^{2}\right)$ & 187.5 & 0.2 \\
Area of EF $\left(\mathrm{km}^{2}\right)$ & 68.9 & 66.9 \\
Area of SF $\left(\mathrm{km}^{2}\right)$ & 12.1 & 9.7 \\
Mean volum. ice content & 8 & 3 \\
in EF $(\%)$ & & \\
Mean volum. ice content & 45 & 15 \\
in SF $(\%)$ & & \\
Vi in EF $\left(\mathrm{km}^{3}\right)$ & 0.069 & 0.039 \\
Vi in SF $\left(\mathrm{km}^{3}\right)$ & 0.072 & \\
\hline
\end{tabular}

\section{Syngenetic ground ice}

The syngenetic cryoformation is associated with a wide variety of modern and Quaternary deposits. It is mainly developed in moraines and fluvioglacial, alluvial, lacustrine and eolian deposits of upper Holocene age. Ground ice in the moraines is mainly formed as a consequence of the burial of glacier margins and the freezing of water contained in clastic rocks. The largest volume of ground ice was found in frontal and lateral Holocene moraines on VI (Table 1). Analysis of several permafrost exposures on northeast VI (Devil Bay) allowed the identification of the different ground-ice types as well as their distribution. Two horizons were usually observed: an upper layer 15-20 m thick with buried glacial ice, and a lower layer of clastic material with infiltration ice. In the first horizon, buried ice is characterized by a typical ribboned structure of glacier ice, large ice crystals of regular shape and the occurrence of clastic material (i.e. englacial drift). In the second horizon, infiltration ice in clastic deposits typically shows a wide variety of cryostructures such as lentil, contact and porous. The volumetric ice content in the lower layer usually does not exceed $40-50 \%$. The contact between frozen moraines and buried ice is commonly diffuse, showing complex deformation structures, both plastic and brittle. Traces of melting at the base of ice deposits and the top of frozen moraines were also observed. They indicate the occurrence of regelation processes of basal water layers. The cryogenic structure of the subglacial moraines is more complex. For Holocene moraines of this type, the distribution of ground ice usually shows a three-layer structure. The uppermost part reveals a massive cryostructure, with constitutional initial ice (i.e. ice that formed simultaneously with the cryoformation) of cement, porous, contact and film types. The volumetric ice content in this layer can reach $20-30 \%$. The middle part is usually composed of structureless ice-rich deposits about 3-5 m thick, with volumetric ice contents up to $40-50 \%$. In the lowermost part, cement and film ice are observed and the total ice content is $5-25 \%$ by volume. Apart from the constitutional initial ice, bottom moraines show other interesting cryostructures such as lenses of thermokarst cave ice with radial morphology. These structures are formed due to the freezing of water in a closed thermokarst

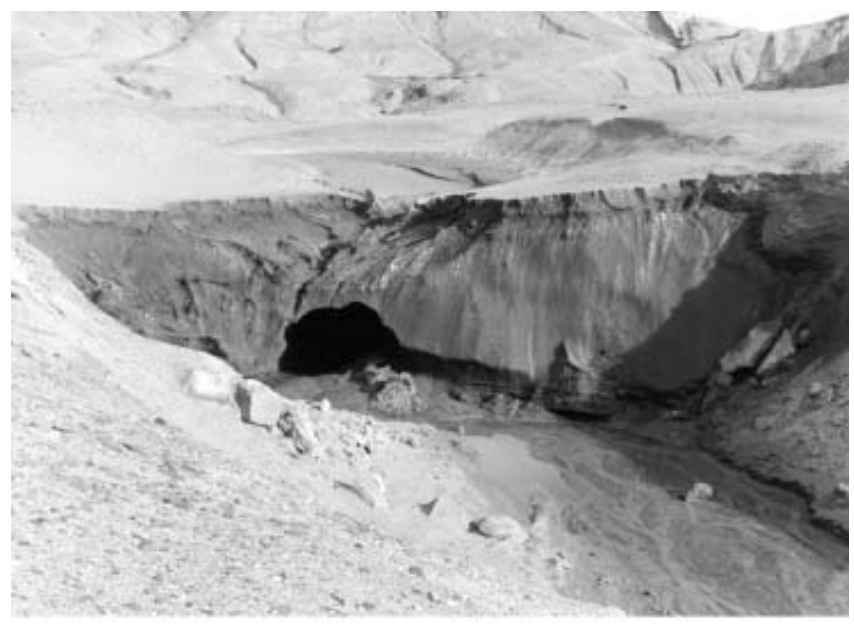

Fig. 4. Buried glacial ice on the western part of SI. The section is about $18 \mathrm{~m}$ high (for location see Fig. 1).

cavity. The occurrence of this process near the top of the permafrost can promote the formation of injected ice which usually shows typical ice lenses.

Syngenetic ground ice on SI occurs within glacial deposits on the top of plateaus and in the western part of the island, mainly in Cross Valley (Fig. 1). Glacial deposits associated with the upper plateaus were found to have insignificant ice content. In this cryoformation, the constitutional initial ice of cement type is dominant and the total ice content does not exceed $7-8 \%$. Deposits associated with moraine fragments at the foot of the slopes of meseta (north Cross Valley) show bodies of buried glacial ice containing erratic blocks. This type of deposit is especially important on the western side of the island. In this sector an outcrop of glacier ice at least $15 \mathrm{~m}$ thick was found covered by a mantle of debris and eolian loam (Fig. 4). The frozen ground at the base of the buried ice of this outcrop was mainly composed of porous and basal ground ice.

Observations of ground ice in fluvioglacial deposits on $\mathrm{VI}$ (periglacial plain in Devil Bay) and in alluvium deposits on SI (Long and Cross Valleys) show that the dominant types are segregated and cement ice. Both are formed due to the freezing of water within fine sediments. The volumetric maximum ice content in this type of frozen ground is estimated to be 10-15\%. Surveys made on several permafrost exposures in Cross Valley and Long Valley on SI (Fig. 1) show ground ice developed from buried icing and metamorphic snowpatches, as well as a complex of ground ice within eolian sand and loam. The occurrence of ground ice and total ice content of these cryogenic eolian deposits was found to be highly variable, but the maximum ice content was always observed near the top of the permafrost.

A crude estimation of the amount of ground ice in the permafrost zone on SI and VI was based on remote-sensing and field data. By using the area of known manifestations of ground ice of every cryoformation and the distribution of ground ice on a vertical section, together with thicknesses of ice-bearing permafrost measured in the field, approximate volumes were calculated (Table 1). Though the areal extent of permafrost on each island is roughly similar, the volume of ground ice on VI is more than twice that on SI. This reflects the prevalence of Quaternary glacial deposits with buried glacial ice in the syngenetic cryoformation and the formation of cryoeluvium with upper ice-rich layers. 
Table 2. Morphogenetic classification of ground ice on VI and SI. M is body ice, $\mathrm{T}$ is structural ice, SF is syngenetic permafrost formation and $\mathrm{EF}$ is epigenetic permafrost formation

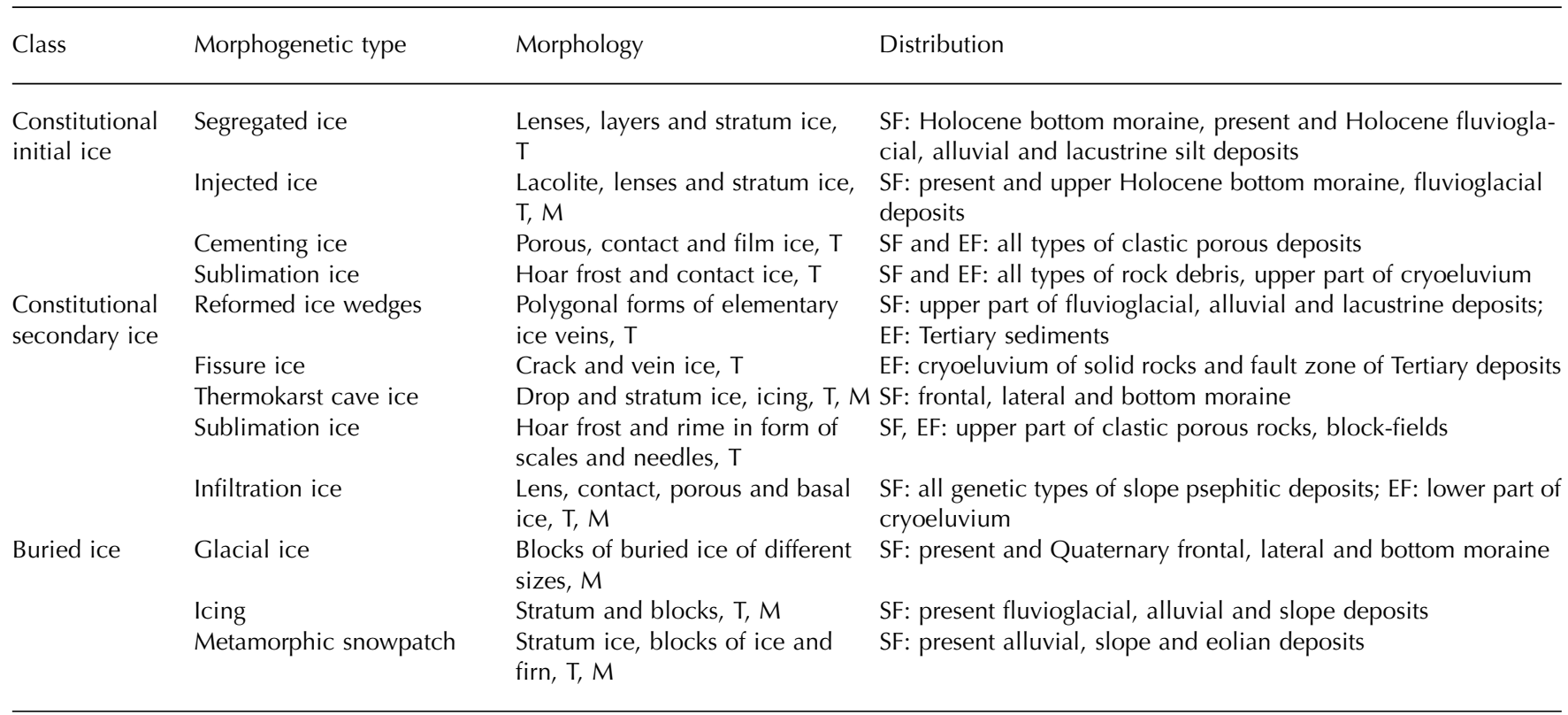

\section{PROPOSED REGIONAL CLASSIFICATION OF GROUND ICE ON THE NORTHEASTERN AP}

The theoretical framework of our classification is based on Shumskii (1964) and Vtyurin (1975). Following these authors, the ground ice was classified on the basis of: (a) the place of formation of the ice with respect to the surface (either above or below), and (b) the synchronicity of ground-ice formation with the existence of permafrost. The first point takes into consideration the mechanisms of formation and origin, whereas the second makes reference to the influence of either surficial or groundwater freezing under different thermodynamic conditions. According to these principles, 12 morphogenetic types of ground ice were determined. Morphologically, two main types of ground ice that can be observed are structural (T) and massive (M) ground ice. The proposed regional scheme for classification of ground ice in permafrost on the northeastern AP is shown in Table 2. Ground-ice distribution is indicated for the principal cryofacies of epigenetic and syngenetic permafrost.

\section{CONCLUSIONS}

Ground ice is extensive within the permafrost zones of $\mathrm{VI}$ and SI down to $20 \mathrm{~m}$ depth. Its formation is controlled by the influence of Holocene deglaciation, climate, the rate of perennial freezing type of material in which it is found, and the occurrence of surface- and groundwater. Two permafrost types are present: epigenetic and syngenetic. On VI, modern and Holocene glacial processes control syngenetic groundice formation, and large bodies of buried glacial ice are found within frontal and lateral moraines. In these deposits, constitutional initial and secondary ice are dominant. In addition, fissure and cement ice are present in weathering crusts of bedrock outcrops of epigenetic permafrost. On SI, syngenetic ground-ice formation is connected to the last stages of glacial periods and the accumulative denudation cycle. Primary development of cryosyngenetic alluvial and eolian sediments associated with icing and metamorphic snowpatches is dominant. The ground-ice volumes in the permafrost zones on SI and VI were estimated as 0.06 and $1.41 \mathrm{~km}^{3}$, respectively. A regional scheme for the classification of ground ice on the northeastern AP is also suggested.

\section{ACKNOWLEDGEMENTS}

We express our gratitude to T. Toconás and J. C. Quinteros for their support during fieldwork on Vega Island. This work is a contribution to projects 'Permafrost, Paleoclima $y$ Geotecnia de la Isla Marambio (Seymour)', funded by Instituto Antártico Argentino-Dirección Nacional del Antártico, and 'A Glacier Baseline Inventory for the Antarctic Peninsula by Means of Remote Sensing Data and GIS Techniques (GLINAP)', funded by Program of Partnership of the Volkswagen Foundation. We also thank R. Waller and G. Casassa for reviews and comments that greatly improved this paper.

\section{REFERENCES}

Corte, A. 1983. Geocryogenic morphology at Seymour Island (Marambio), Antarctica. In Permafrost, Fourth International Conference. Proceedings. Washington, DC, National Academy Press, 192-197. (17-22 July 1983, Fairbanks, AK.)

De Angelis, H., E. Ermolin and P. Skvarca. 2002. Geomorfología de la Bahía del Diablo, Isla Vega, Península Antártica. In Cabaleri, N., C. A. Cingolani, E. Linares, M. G. López de Luchi, H. A. Ostera and H. O. Panarello, eds. Actas del XV Congreso Geológico Argentino. Vol. II. Buenos Aires, Asociación Geológica Argentina, 469-473.

Ermolin, E. and H. De Angelis. 2002. Procesos exógenos en el permafrost de la Isla Marambio (Seymour), Península Antártica. In Cabaleri, N., C. A. Cingolani, E. Linares, M. G. López de Luchi, H.A. Ostera and H. O. Panarello, eds. Actas del XV Congreso Geológico Argentino. Vol. II. Buenos Aires, Asociación Geológica Argentina, 463-468. 
Ermolin, E., H. De Angelis and P. Skvarca. 2002a. Estudio geotécnico de la pista de Base Marambio, Isla Marambio (Seymour), Península Antártica. Buenos Aires, Instituto Antártico Argentino, Contribución No. 536.

Ermolin, E., H. De Angelis and P. Skvarca. 2002b. Mapping of permafrost on Vega Island, Antarctic Peninsula, using satellite images and aerial photography. Ann. Glaciol., 34, 184-188

Fournier, H. P., E. M. Buk and A. E. Corte. 1990. Three permafrost conditions indicated by geophysical soundings in Tertiary sediments at Seymour Island, Antarctic Peninsula. Cold Reg. Sci. Technol., 17(3), 301-307.

Fukuda, M., J. A. Strelin, K. Shimokawa, N. Takahashi, T. Sone and D. Trombotto. 1992. Permafrost occurrence of Seymour Island and James Ross Island, Antarctic Peninsula region. In Yoshida, Y., K. Kaminuma and K. Shiraishi, eds. Recent progress in Antarctic earth sciences. Tokyo, Terra Scientific Publishing Co., 745-750.

Ingólfsson, O. and 10 others. 1998. Antarctic glacial history since Last Glacial Maximum: an overview of the record on land. Antarct. Sci., 10(3), 326-344.

Kato, K., A. M. Corte and M. Fukuda. 1990. Chemical and isotopic characteristics of ice from an ice-wedge in Seymour Island (Isla V. Com. Marambio), Antarctic Peninsula region. Proc. NIPR Symp. Antarct. Geosci., 4, 181-190.

Kudryavtsev, V.A. 1979. Metodika merzlotnoi svyomki. Moscow, Moscow State University.

Rabassa, J., P. Skvarca, L. Bertani and E. Mazzoni. 1982. Glacier inventory of James Ross and Vega Islands, Antarctic Peninsula. Ann. Glaciol., 3, 260-264.

Shumskii, P. A. 1964. Principles of structural glaciology. New York, Dover Publications.

Skvarca, P., W. Rack, H. Rott and T. Ibarzábal y Donángelo. 1998. Evidence of recent climatic warming on the eastern Antarctic Peninsula. Ann. Glaciol., 27, 628-632.

Suetova, I.A. 1968. Osnovnye morfometricheskie kharakteristiki Antarktidy. Moscow, Akademiia Nauk SSSR.

Vtyurin, B.I. 1975. Podzemnye l'dy SSSR. Moscow, Izdateltsvo Nauka.

Washburn, A.L. 1979. Geocryology: a survey of periglacial processes and environments. London, Edward Arnold.

Zale, R. and W. Karlén. 1989. Lake sediment cores from the Antarctic Peninsula and surrounding islands. Geogr. Ann., 71A(3-4), 211-220. 